\title{
Psikoedukasi Kecerdasan Emosional dalam Rangka Penyesuaian Diri dengan Nilai-Nilai Sekitar Pada Calon Imam Katolik
}

\author{
Ka Yan \\ Fakultas Psikologi, Universitas Kristen Maranatha \\ Jl. Surya Sumantri no 65, Bandung \\ kresentia_kayan@yahoo.com
}

\begin{abstract}
Abstrak - Hidup sebagai imam (pemuka agama katolik) yang diharuskan menjalani kehidupan membiara di berbagai tempat dan perlu berkiprah di tengah umat yang memiliki kemajemukan karakteristik dan persoalan merupakan hal yang tidak mudah untuk dijalani. Selain didasari oleh adanya motivasi yang kuat yang bersumber dari dalam diri, perlu juga diperlengkapi dengan sejumlah pengetahuan dan ketrampilan agar mampu beradaptasi. Untuk itu, sebelum ditahbiskan menjadi imam, maka calon pemuka agama katolik perlu menempuh pendidikan dalam waktu yang cukup lama. Pada tahun pertama, mereka menjalani pendidikan dan mendapat sebutan 'postulan', dan kecerdasan emosional merupakan salah satu topik psikoedukasi yang diangkat dalam tahapan ini. Para postulan diharapkan dapat lebih mampu mengenali emosi mereka maupun oranglain, mampu mengelolanya dan mampu menjalin relasi dengan oranglain sesuai dengan situasi, nilai-nilai dan budaya setempat yang dianut masyarakat setelah mengikuti kegiatan ini. Metode psikoedukasi yang diterapkan adalah ceramah dan diskusi, beserta pengisian kuesioner kecerdasan emosi maupun evaluasi. Hasil yang diperoleh dari kegiatan psikedukasi ini adalah para postulan mendapatkan pemahaman tentang kecerdasan emosi yang tinggi, yaitu pada area pengenalan emosi diri $(81,25 \%)$ dan membina hubungan dengan orang lain $(81,25 \%)$. Dengan demikian, kegiatan psikoedukasi ini memberikan manfaat bagi pengembangan diri postulan dan akan dilanjutkan pada tahun berikutnya.
\end{abstract}

Kata kunci: psikoedukasi, kecerdasan emosional, calon imam, postulan

Abstract - Life as a pastor (catholic religious leader) who should experience living in a monastery in various places and needs to take a part in society with plurality and problems definitely is not an easy way. Besides motivation as a based, pastors should be equipped with knowledge and skills in order to adapt. Therefore, before appointing as pastors, they should follow education in a long time period. In the first year, they undergo education (they are called as 'postulan'), and emotional intelligence psychoeducation is one of the topic that is discussed in this stage. After attending this psychoeducation, postulans are expected to more recognize their and other people emotions, can manage them and build social relationships with others that suitable with situation, values and local cultures that are embraced by the society. Lecture, discussion, fill in the emotional intelligence questionnaire and evaluation were the methods in this psychoeducation. Result from this psychoeducation is postulans have high score in emotional intelligence, specially in knowing emotions $(81,25 \%)$ and maintaining relation with others $(81,25 \%)$ area. Therefore, this psychoeducation gives benefit for postulans' development and will be continue in the next year.

Keywords: psychoeducation, emotional intelligence, pastors, postulan

\section{PENDAHULUAN}

'Imam' (pemuka agama katolik) merupakan suatu panggilan hidup yang tidak mudah dijalani. Berbeda dengan manusia pada umumnya yang berkeluarga, menjadi imam berarti tidak mungkin menikah. Imam menjalani hidup dengan mengacu pada 3 kaul yaitu kemurnian, ketaatan dan kemiskinan dengan konsekuensi hidup selibat sepanjang hidupnya [1]. Selain itu, imam harus menjalani kehidupan yang sederhana yang diwujudkan dengan melepaskan diri dari uang, harta dan barang-barang yang memuaskan keinginan pribadi. Meskipun seorang imam tinggal bersama imam-imam yang lain dalam suatu komunitas, namun kesunyian tetap menjadi inti kehidupan mereka [2].

Berbagai masalah pun tidak jarang menghampiri imam dalam kehidupan membiaranya, sekaligus diperhadapkan pada masyarakat dengan keberagaman karateristik maupun masalah. Imam perlu mendedikasikan seluruh hidupnya untuk kegiatan rohani dan menyingkirkan kepentingan 
pribadi [3], sementara di sisi lain mereka tetaplah manusia yang tidak lepas dari karakteristiknya. Dari sudut pandang psikologi, salah satu tugas perkembangan yang perlu dijalani manusia adalah membangun relasi dengan lawan jenis (intimacy) yang dilanjutkan ke jenjang pernikahan [4]. Dengan demikian, tidaklah mengherankan jika kesepian menjadi salah satu permasalahan yang dihadapi imam [3]. Selain itu posisi sebagai imam yang merupakan panutan umat dalam menjalani kehidupan mengakibatkan seorang imam dituntut menampilkan kepribadian yang sempurna, meskipun bisa saja seorang imam tengah mengalami krisis iman yang mengakibatkan stres, depresi, karya pelayanan terganggu dan bahkan meninggalkan panggilannya [5].

Perjalanan menjadi seorang imam membutuhkan waktu yang tidak singkat, yaitu delapan sampai sepuluh tahun masa pendidikan dan pembinaan (setelah SMA) [6], yang juga perlu didasari motivasi yang kuat. Pada tahun pertama, calon pemuka agama katolik akan menjalani masa sebagai postulan, yaitu masa peralihan dan perkenalan bagi calon pemuka agama katolik agar dapat berorientasi dan mengenal kehidupan membiara, khususnya pada kongregasi (komunitas) yang dipilih. Selain mendapatkan materi berupa pengetahuan seperti bahasa Inggris dan filsafat, pada masa ini para postulan mulai diperkenalkan hidup yang 'sunyi', yang mana mereka meninggalkan keluarga mereka untuk tinggal bersama dengan postulan lain dan dibatasi akses komunikasi (mereka tidak dapat menggunakan gadget untuk berinteraksi dengan keluarga maupun teman-teman di luar postulan) maupun pergerakannya (tidak dapat meninggalkan kediaman kongregasi). Hal tersebut tentunya secara umum berlawanan dengan tahapan perkembangan para postulan yang rata-tata berada dalam usia transisi remaja ke dewasa, yang dikenal dengan emerging adulthood. Pada tahap ini, individu tengah banyak melakukan eksplorasi dan eksperimen terkait percintaan maupun pekerjaan, mencari kestabilan dalam pekerjaan [4] (misal dengan mencari nafkah/ mempersiapkan diri dengan ketrampilan untuk bekerja dan mandiri secara finansial), yang tidak menjadi orientasi saat menjalani masa sebagai postulan.

Para postulan pun perlu menjalani kehidupan yang sederhana dan mandiri dengan mengurus dirinya sendiri, seperti memasak dengan bahan ala kadarnya, mencuci dan mengepel. Tidak jarang perubahan pola hidup membuat para postulan merasa tertekan dan tidak melanjutkan pendidikan, seperti halnya yang terjadi di Kongregasi ' $Y$ ' Yogyakarta, yang mana pada setiap tahun ditemukan fenomena postulan yang mengundurkan diri dengan kisaran $10 \%$ dari total angkatan, yang dalam kurun waktu +/- 3 tahun mengalami peningkatan postulan yang keluar sebesar dua kali lipat. Beberapa hal spesifik yang membuat mereka tidak melanjutkan pendidikan adalah perbedaan bahasa, budaya, rutinitas, kecenderungan menarik diri dan enggan mengikuti aturan dan kegiatan yang berlaku [7].
Adapun yang menjadi harapan pihak kongregasi pada masa postulan adalah mampu mengenal dirinya dan menjadi pribadi yang dewasa dengan mengembangkan nilai-nilai kepribadian, mengolah hidup dan mengarahkan emosi [7], yang berujung pada kemantapan dalam menjalani pilihannya untuk hidup selibat (tidak menikah), meskipun juga tidak tertutup kemungkinan setelah menjalani masa postulan dan mempertimbangkan berbagai sisi secara matang, postulan menyadari bahwa kehidupan membiara bukanlah hal yang sesuai untuknya. Dengan demikian, masa ini pun merupakan masa evaluasi, baik dari sisi pribadi postulan maupun dari sisi penyelenggara. Apabila postulan dinyatakan lulus, maka akan melanjutkan pendidikan ke tempat (kota) yang berbeda dan memasuki masa sebagai novisiat, dengan tantangan yang lebih meningkat.

Untuk mewujudkan tujuan dari pendidikan postulan, maka kongregasi ' $X$ ' Bandung memandang perlunya pembekalan dari sisi psikologi. Hal ini dilakukan dengan bekerjasama dengan pengajar dari Fakultas Psikologi Universitas Kristen Maranatha melalui kegiatan Pengabdian kepada Masyarakat (PkM) yang diselenggarakan secara rutin selama 1 tahun penuh. Beragam materi psikologi diberikan kepada postulan, baik yang sifatnya teoritik maupun yang langsung dapat diaplikasikan ke dalam kehidupan sehari-hari. Salah satu topik yang diangkat adalah kecerdasan emosional, yang merupakan kapasitas untuk menghasilkan analisa yang tepat tentang emosi dan kapasitas untuk menggunakan perasaan, emosi dan pengetahuan emosional untuk meningkatkan pemikiran, menggabungkan keahlian tertentu dan menganggapnya sebagai satu kesatuan yang utuh [8]. Kecerdasan emosional dapat dimanfaatkan untuk memotivasi diri sendiri dan bertahan menghadapi frustrasi, mengendalikan dorongan hati dan tidak melebihi batas, mengatur suasana hati agar beban stres tidak melumpuhkan kemampuan berpikir, berempati dan berdoa [9]. Meskipun kecerdasan emosional sudah muncul pada tahun 1990an, namun terus mengalami perkembangan dan pemanfaatannya masih relevan hingga masa kini [8] [10], termasuk untuk para postulan yang menjalani hidup berbeda dengan masyarakat pada umumnya. Setelah mengikuti kegiatan PkM ini, para postulan diharapkan dapat lebih mampu mengenali emosi mereka maupun oranglain, mampu mengelolanya dan mampu menjalin relasi dengan oranglain sesuai dengan situasi, nilai-nilai dan budaya setempat yang dianut masyarakat.

\section{METODE PELAKSANAAN}

PkM ini dilaksanakan dalam bentuk psikoedukasi dengan metode ceramah dan diskusi, disertai pengisian kuesioner kecerdasan emosi yang mengacu pada teori Goleman [9]. Kegiatan ini dilakukan dengan melibatkan 16 orang postulan yang umumnya berasal dari luar pulau Jawa dan mereka tinggal bersama di kongregasi ' $\mathrm{X}$ ' Bandung. 
Psikoedukasi kecerdasan emosional dilaksanakan pada hari Kamis, 1 April 2021 sebanyak 1 (satu) kali dengan durasi 2 jam, dan terdiri dari 2 sesi. Sesi pertama diawali dengan pemaparan materi mengenai emosi secara umum selama 30 menit agar postulan memperoleh gambaran singkat mengenai topik yang akan dibahas, kemudian dilanjutkan dengan tanya jawab singkat dan mengisi kuesioner selama 30 menit. Selanjutnya postulan diperkenankan menghitung skor yang diperoleh (15 menit) untuk mengetahui derajat kecerdasan emosi yang dimiliki sehingga mendapatkan gambaran yang lebih rinci mengenai dirinya sendiri, yang dilanjutkan dengan pembahasan dan tanya jawab mengenai kuesioner tersebut pada sesi kedua selama 45 menit.

Berikut penjelasan mengenai kegiatan PkM yang terdiri dari beberapa tahapan, yaitu:

Tahap 1

Tahap ini merupakan tahap persiapan, dan dilakukan 2 minggu sebelum pelaksanaan. Persiapan berupa mencari bahan mengenai kecerdasan emosional yang sesuai, menyiapkan PPT dan memperbanyak kuesioner sesuai jumlah peserta. Pada hari kegiatan (sebelum pelaksanaan), narasumber memeriksa kembali hal-hal yang sudah disiapkan untuk memastikan tidak ada yang terlewat. Selain itu, sehubungan kegiatan akan dilakukan dalam bentuk tatap muka langsung (offline) dalam masa pandemi, maka para postulan maupun narasumber menyiapkan APD dan memastikan kondisi kesehatan. Setiap pihak yang akan mengikuti kegiatan pun dipastikan telah menjalani vaksinasi sebanyak 2 kali.

\section{Tahap 2}

Tahap ini merupakan tahap awal pelaksanaan, dimulai dengan doa dan narasumber menyebutkan topik yang akan dibahas, sekaligus tujuan dari kegiatan ini. Topik kecerdasan emosional merupakan salah satu dari bagian materi psikologi yang diberikan secara rutin setiap minggu oleh dosen-dosen dari Fakultas Psikologi Universitas Kristen Maranatha, sehingga narasumber juga memaparkan keterkaitan topik ini dengan topik yang lain. Selain itu, narasumber memaparkan teknis pelaksanaan berikut aturan yang akan dilaksanakan dalam kegiatan ini, termasuk wajib memakai APD.

\section{Tahap 3}

Tahap ini merupakan tahap pelaksanaan sesi 1, yang dimulai dengan ice breaking yang mana para postulan diminta untuk menebak emosi yang ditayangkan melalui gambar. Setelah itu, narasumber memaparkan materi tentang emosi, meliputi apa itu emosi, manfaat emosi sebagai bentuk adaptasi [11], perkembangan emosi pada manusia, khususnya pada masa remaja akhir dan dewasa awal, yang merupakan masa yang sesuai dengan usia postulan. Narasumber juga memaparkan bahwa emosi itu tidak selalu negatif dengan tujuan meluruskan mispersepsi yang sering terjadi di kalangan masyarakat pada umumnya. Di akhir sesi 1, narasumber mempersilakan postulan bertanya maupun berbagi terkait pengalaman emosi, seperti emosi dominan apa yang dirasakan muncul saat masa anakanak dan perbedaannya dengan masa saat ini. Tujuannya adalah untuk membuat para postulan benar-benar mengerti perubahan emosi yang umumnya terjadi berdasarkan tahapan perkembangannya.

Tahap 4

Tahap ini merupakan tahap pelaksanaan sesi 2, yang dimulai dengan postulan mengisi kuesioner kecerdasan emosi. Agar postulan mendapatkan gambaran dirinya dengan akurat, maka postulan melakukan scoring terkait kuesionernya secara pribadi (narasumber mengingatkan tidak perlu ditunjukkan kepada pihak lain), kemudian narasumber membahas pengertian dari aspek-aspek kecerdasan emosi yang diukur melalui kuesioner. Narasumber menjelaskan terdapat 3 kategori derajat penilaian yaitu tinggi, sedang dan kurang. Tinggi artinya kekuatan, sedang artinya masih memerlukan perhatian (ada hal yang perlu ditingkatkan) dan rendah merupakan point krusial yang perlu segera ditingkatkan. Narasumber juga menjelaskan bagaimana mengekspresikan emosi yang dapat diterima/ selaras dengan nilai-nilai sekitarnya. Di akhir sesi 2, postulan diberi kesempatan untuk bertanya jika ada yang tidak dipahami maupun sharing (jika berkenan) mengenai hasil kuesioner kecerdasan emosinya.

\section{Tahap 5}

Tahap ini merupakan tahap penutup, narasumber mengucapkan terimakasih dan meminta postulan menulisan kesan-kesan mengenai kegiatan psikoedukasi yang telah dilaksanakan sebagai bentuk evaluasi, dan diakhiri dengan doa. Keseluruhan kegiatan dilaksanakan dengan protokol kesehatan yang ketat.

\section{Tahap 6}

Narasumber memproses keseluruhan hasil kuesioner kecerdasan emosi dan evaluasi para postulan dengan menggunakan metode deskriptif kuantitatif. Metode ini berupa penelitian guna memaparkan data untuk memperoleh gambaran yang jelas dengan menganalisis data. Penekanan metode deskriptif kuantitatif adalah pada aspek pengukuran secara obyektif terhadap fenomena sosial [12].

\section{DISKUSI}

Berdasarkan kegiatan psikoedukasi, diperoleh hasil bahwa $50 \%$ postulan memiliki derajat kecerdasan emosi yang tinggi dan 50\% memiliki derajat emosi yang sedang (gambar 1). Goleman [9] menyatakan terdapat 5 aspek dalam kecerdasan emosional, yaitu 1) memahami emosi sendiri, 2) mampu mengelola emosi sendiri, 3) memotivasi 
diri sendiri, 4) memahami emosi orang lain dan 5)mampu membina hubungan sosial. Pada kegiatan psikoedukasi ini, aspek yang menonjol adalah memahami emosi diri dan emosi orang lain (aspek 1 dan 5), yang mana mayoritas postulan memiliki derajat yang tinggi $(81,25 \%)$, sedangkan pada aspek mengelola emosi, memotivasi diri dan membina hubungan sosial (aspek 2, 3, dan 4) mayoritas postulan memiliki derajat yang sedang $(68,75 \%$ untuk aspek dua dan tiga, dan 62,75\% untuk aspek keempat; gambar 2 dan table I).

\section{Kecerdasan Emosi Postulan}

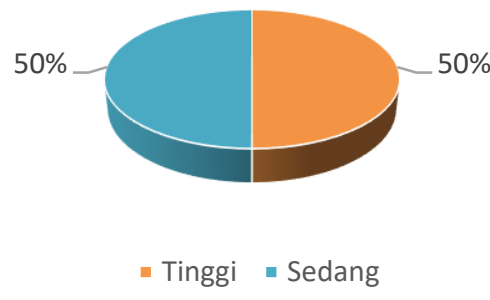

Gambar 1 Diagram Kecerdasan Emosi Postulan Secara Umum

Aspek memahami emosi sendiri artinya para postulan segera menyadari emosi apa yang muncul, baik yang positif (seperti senang) maupun negatif (seperti kesal, marah), mengetahui ketika dirinya stress ataupun cemas. Menurut Goleman [9] aspek ini merupakan fondasi utama dari aspekaspek yang lain karena merupakan hal penting untuk memahami kejiwaan secara mendalam. Terdapat ciri-ciri pada aspek ini, yaitu kesadaran emosi (mengenali emosi dan dampaknya), menilai diri secara teliti (mengerti kelebihan maupun kekurangan, mampu belajar dari pengalaman), dan percaya diri (yakin terhadap kemampuan sendiri dan memiliki harga diri).

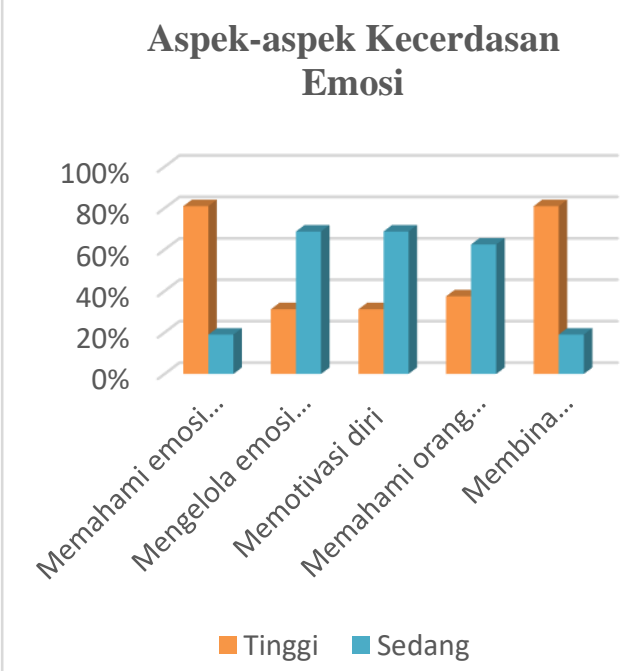

Gambar 2 Diagram Aspek-Aspek Kecerdasan Emosi
Aspek mengelola emosi artinya para postulan tidak terlarut dalam situasi buruk, masih dapat mengelola moodnya tanpa bantuan orang lain, dapat menahan mengungkapkan emosi jika dianggap tidak tepat dengan situasi sekitar dan tidak mudah terganggu dengan tanggapan pihak lain yang tidak menyenangkan. Menurut Goleman [9], aspek ini menggambarkan kemampuan individu dalam menangani perasaan agar dapat terungkap dengan tepat atau selaras, yang berarti bukan untuk menekan maupun menyembunyikan gejolak perasaan, namun bukan pula langsung mengungkapkan apa yang dirasakan. Tujuan dari pengelolaan emosi adalah untuk menjaga kesimbangan emosi. Dalam kaitannya dengan para postulan, narasumber memaparkan berarti perlu mengekspresikan emosi dengan tetap mempertimbangkan situasi sekitar, seperti budaya setempat sehingga pengekspresian emosi dapat diterima lingkungan

Aspek memotivasi diri artinya para postulan cukup mampu membuat pilihan/ prioritas dan menjalankannya meskipun menghadapi kesulitan, sehingga mampu menyelesaikan apa yang menjadi tugas/ tanggungjawabnya. Goleman [9] menyebutkan terdapat empat kecakapan utama dalam aspek ini yaitu adanya dorongan berprestasi (dorongan untuk mencapai lebih dari standar), komitmen (menyelaraskan diri dengan sasaran kelompok/ lembaga), inisiatif (bersiap untuk mengambil kesempatan yang terbuka) dan optimis (tetap gigih memperjuangkan pencapaian sasaran meskipun menghadapi rintangan maupun kegagalan). Dalam kaitannya dengan para postulan, narasumber memaparkan artinya mereka perlu mempertimbangkan apa yang menjadi tujuan kongregrasi dan menunjukkan kesungguhan untuk mencapai tujuan tersebut.

Aspek memahami emosi oranglain bermanfaat saat berhadapan dengan sesama, yang mana postulan masih dapat mengerti emosi positif maupun negatif dan dapat menempatkan diri pada posisi orang lain (berempati). Goleman [9] menyatakan ciri-ciri empati adalah memahami dari sudut pandang orang lain dan menunjukkan ketertarikan terhadap kepentingan mereka, yang memudahkannya mengenali dan berujung pada usaha memenuhi kebutuhan/ mengembangkan oranglain dan mampu membaca 'arus-arus emosi'dalam sebuah kelompok, meskipun tidak ditampilkan secara eksplisit. Narasumber memaparkan, dalam aspek ini berarti para postulan dapat berempati terhadap kondisi rekannya, termasuk yang melatarbelakangi, seperti budaya tempat postulan berasal.

Pemahaman terhadap emosi juga bermanfaat bagi para postulan saat membangun relasi dengan pihak lain, yaitu dengan sering menunjukkan antusiasme dan kesediaan postulan untuk mendengarkan, menyesuaikan diri dengan beragam karakter, yang memudahkannya menjalin 
pertemanan dengan masyarakat yang beragam. Goleman [9] menyatakan individu yang memiliki ketrampilan sosial akan pandai menanggapi orang lain dengan memberikan respon yang tepat, sementara individu yang tidak memiliki ketrampilan ini akan tampak angkuh, sombong, tidak berperasaan yang pada akhirnya dijauhi oranglain. Narasumber menjelaskan, dalam aspek ini berarti postulan dapat menjalin hubungan baik dengan sekitarnya.

Tabel I Rincian Aspek-Aspek Kecerdasan Emosi

\begin{tabular}{|l|c|c|}
\hline $\begin{array}{c}\text { Aspek- } \\
\text { AspekKecerdasan } \\
\text { Emosi }\end{array}$ & $\begin{array}{c}\text { Tinggi (jumlah } \\
\text { dan persentase) }\end{array}$ & $\begin{array}{c}\text { Sedang (jumlah } \\
\text { dan persentase) }\end{array}$ \\
\hline Memahami emosi & 13 orang & 3 orang \\
diri & $81,25 \%$ & $18,75 \%$ \\
\hline Mengelola emosi & 5 orang & 11 orang \\
diri & $31,25 \%$ & $68,75 \%$ \\
\hline Memotivasi diri & 5 orang & 11 orang \\
& $31,25 \%$ & $68,75 \%$ \\
\hline Memahami emosi & 6 orang & 10 orang \\
orang lain & $37,50 \%$ & $62,50 \%$ \\
\hline Membina hubungan & 13 orang & 3 orang \\
dengan orang lain & $81,25 \%$ & $18,75 \%$ \\
\hline
\end{tabular}

Para postulan memiliki kekuatan dalam aspek memahami emosi diri dan membina hubungan dengan orang lain (kedua aspek ini berada dalam derajat tinggi), sementara dalam 3 aspek lainnya (mengelola emosi diri, memotivasi diri dan memahami emosi orang lain berada dalam derajat sedang), masih membutuhkan perhatian untuk ditingkatkan. Meskipun demikian, 3 aspek ini secara umum cukup dimiliki oleh para postulan.

Adapun kesan yang diperoleh para postulan terhadap kegiatan ini adalah menarik dan bermanfaat (100\%). Para postulan menyatakan bahwa mereka dapat menggunakan pemahamannya terkait psikologi untuk lebih mengenali hakikat manusia yang merupakan makhluk sosial dan bagaimana usia menjadi pertimbangan dalam menampilkan emosinya. Para postulan juga secara spesifik dapat mengungkapkan emosi apa yang dipandang sebagai kekuatan dan emosi apa yang dipandang sebagai hal yang masih perlu diperbaiki, dan bagaimana emosi tersebut muncul dalam diri mereka.

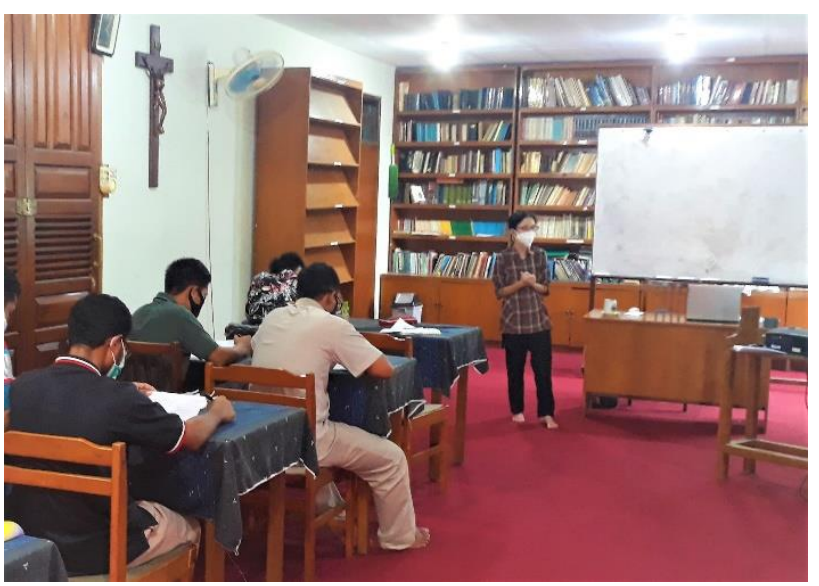

Gambar 4 Situasi Psikoedukasi Kecerdasan Emosional

\section{KESIMPULAN}

Psikoedukasi kecerdasan emosi memberikan manfaat bagi pengembangan diri para postulan dalam hal menjalani pendidikan saat ini (mereka hidup jauh dari keluarga dan 'melepaskan diri' dari kontak sosial sekitar). Melalui kegiatan ini, mereka mendapatkan pemahaman dalam pengenalan emosi diri, pengelolaan emosi diri, memotivasi diri, pengenalan emosi orang lain dan membina relasi dengan sekitar yang memiliki nilai-nilai yang berbeda. Kegiatan ini juga menjadi bekal bagi mereka untuk menempuh pendidikan selanjutnya dan menjalani kehidupan membiara kelak saat ditahbiskan menjadi imam. Kegiatan psikoedukasi ini akan tetap dilaksanakan pada tahun berikutnya.

\section{UCAPAN TERIMAKASIH}

Narasumber menghaturkan terimakasih kepada LPPM Universitas Kristen Maranatha yang telah mendukung terlaksananya kegiatan ini, baik dalam bentuk material maupun non-material, Kongregasi ' $\mathrm{X}$ ' Bandung yang memberikan kesempatan dan keterbukaan, dan juga kepada para postulan yang telah bersedia mengikuti kegiatan ini.

\section{DAFTAR PUSTAKA}

[1] M. P. P. Sari and I. Setyawan, "Pengalaman Menjadi Biarawati Katolik: Studi Kualitatif Intepretative Phenomenological Analysis," Jurnal Empati, vol. 6, no. 1, pp. 287-290, 2017.

[2] P. Widyantono and A. Ediati, "Memahami Kebahagiaan Melalui Perjalanan Membiara Para Rahib Trapis di Pertapaan Santa Maria Rawaseneng: Studi Fenomenologis dengan Metode Intepretatitve Phenomenological Analysis," Jurnal Empati, vol. 7, no. 4, pp. 1319, 2018.

[3] A. Utama, "BBC Indonesia," 14 Oktober 2017. [Online]. Available: https://www.bbc.com/indonesia/indonesia-41609461. [Accessed 28 Agustus 2021].

[4] J. Santrock, Life Span Development 13th, New York: McGraw-Hill, 2011.

[5] D. Wibowo, "Dinamika Pengalaman Krisis Dalam Kehidupan Pastor," Fakultas Psikologi, Yogyakarta, 2013.

[6] A. Gunadi, "Tahapan Proses Individuasi Imam Diosesan: Kajian Arketip Melalui Spritualitas, Kompetensi Dasar dan Kesejahteraan Psikologis dalam Pelayanan Pastoral-Teritorial di Regio Jawa," Fakultas Psikologi Universitas Katolik Indonesia Atmajaya, Jakarta, 2021.

[7] B. Najak, "Kesulitan Hidup Membiara Para Postulan di Yogyakarta (Studi Deskriptif Pada Postulan Mengikuti Kursus Bina Awal di Yogyakarta Tahun 2016/2017)," Fakultas Keguruan dan Ilmu Pendidikan Universitas Sanata Dharma, Yogyakarta, 2017.

[8] G. Abdukman, Z. Hatipoglu and Z. Yuksekbilgili, "A research about emotional intelligence on generations," International Journal of Advance Multidisiplinary Research and Review, vol. 3, no. 4, pp. 124-133, 2015. 
[9] D. Goleman, Kecerdasan Emosional Untuk Mencapai Puncak Prestasi, Jakarta: Gramedia Pustaka Utama, 1999.

[10] P. Connor, A. Hill, M. Kaya and B. Martin, "The measurement of emotional intelligence: a critical review of the literature and recommendations for researchers and practitioners," Frontiers in Psychology, vol. 10, p. 1661, 2019.

[11] Sugiyono, Metode Penelitian Kuantitatif dan Kualitatif, Bandung: Alphabet, 2014.

[12] J. Prawitasari, "Kecerdasan emosi," Buletin Psikologi, vol. 1, pp. 21 $31,1995$. 